\title{
Ovaries of Tubificinae (Clitellata, Naididae) resemble ovary cords found in Hirudinea (Clitellata)
}

\author{
Anna Z. Urbisz $\cdot$ Mariola Krodkiewska • \\ Piotr Świątek
}

Received: 29 March 2010/Revised: 19 October 2010/Accepted: 20 October 2010/Published online: 3 November 2010

(C) The Author(s) 2010. This article is published with open access at Springerlink.com

\begin{abstract}
The ultrastructure of the ovaries and oogenesis was studied in three species of three genera of Tubificinae. The paired ovaries are small, conically shaped structures, connected to the intersegmental septum between segments $\mathrm{X}$ and XI by their narrow end. The ovaries are composed of syncytial cysts of germ cells interconnected by stable cytoplasmic bridges (ring canals) and surrounded by follicular cells. The architecture of the germ-line cysts is exactly the same as in all clitellate annelids studied to date, i.e. each cell in a cyst has only one ring canal connecting it to the central, anuclear cytoplasmic mass, the cytophore. The ovaries found in all of the species studied seem to be meroistic, i.e. the ultimate fate of germ cells within a cyst is different, and the majority of cells withdraw from meiosis and become nurse cells; the rest continue meiosis, gather macromolecules, cell organelles and storage material, and become oocytes. The ovaries are polarized; their narrow end contains mitotically dividing oogonia and germ cells entering the meiosis prophase; whereas within the middle and basal parts, nurse cells, a prominent cytophore and growing oocytes occur. During late previtellogenesis/early vitellogenesis, the oocytes detach from the cytophore and
\end{abstract}

Communicated by T. Bartolomaeus.

A. Z. Urbisz · P. Świątek $(\bowtie)$

Department of Animal Histology and Embryology,

Silesian University, Bankowa 9, 40-007 Katowice, Poland

e-mail: piotr.swiatek@us.edu.pl

A. Z. Urbisz

e-mail: afuchs@us.edu.pl

M. Krodkiewska

Department of Hydrobiology, Silesian University,

Bankowa 9, 40-007 Katowice, Poland

e-mail: mariola.krodkiewska@us.edu.pl float in the coelom; they are usually enveloped by the peritoneal epithelium and associated with blood vessels. Generally, the organization of ovaries in all of the Tubificinae species studied resembles the polarized ovary cords found within the ovisacs of some Euhirudinea. The organization of ovaries and the course of oogenesis between the genera studied and other clitellate annelids are compared. Finally, it is suggested that germ-line cysts formation and the meroistic mode of oogenesis may be a primary character for all Clitellata.

Keywords Annelida - Oligochaeta - Oogenesis . Germ-cell cysts $\cdot$ Nurse cells $\cdot$ Follicular cells

\section{Introduction}

Annelids possessing an epidermal, glandular structure in the shape of a ring (clitellum) and producing cocoons during the breeding season form the taxon, Clitellata, whose monophyly is well supported by many morphological characters and molecular data (Purschke et al. 1993; Nielsen 1995; Westheide 1997; Ferraguti 2000; McHugh 1997, 2000; Siddall et al. 2001; Purschke 2002; Rousset et al. 2007, 2008). Despite many morphological or/and molecular studies, the origin and phylogenetic relationships among groups of clitellate annelids are still far from being resolved (Erséus 2005; Rousset et al. 2008), and it is obvious that more data are needed.

One of the morphological characters supporting clitellate monophyly is its hermaphrodism and the organization of its reproductive system (Erséus 2005; Jamieson 2006). The segmental position of its genital organs is group specific and was used to infer the phylogeny of oligochaetous clitellates (Brinkhurst 1982, 1984a, b). In contrast to 
spermatogenesis and sperm morphology, which have been well studied in Clitellata and have been used many times in phylogenetic analyses (e.g. Erséus and Ferraguti 1995; Ferraguti and Erséus 1999, Marotta et al. 2003, 2008), the ovary structure and the course of oogenesis, especially in species of oligochaetous clitellates, are still poorly known.

Recently, several papers devoted to ovary morphology and oogenesis in species of Euhirudinea have been published (Spałek-Wołczyńska et al. 2008; Świątek 2005a, b, 2006, 2008; Ben Ahmed et al. 2010; Świątek et al. 2010). From those papers and from older literature (Damas 1964, 1977; Aisenstadt 1964; Fischer and Weigelt 1975; Fernández et al. 1992), we know that in euhirudinean species the ovaries are composed of an ovisac (a diverticulum of the coelom) and internal structures usually in the form of solid cords (ovary cords), whose morphology varies between leech groups (for details of the organization of ovaries in true leeches, see Świątek 2008; see also "Discussion"). In all hirudinean species studied to date, oogenesis is meroistic (nutrimental); i.e. during early oogenesis germ-line cysts (clusters, clones, nests, morulae) are formed within the ovary cords, and the ultimate fate of germ cells united into a cyst is different. The majority of germ cells become nurse cells; the rest (sometimes only one) continue meiosis, grow and become future egg cell(s) (Świątek et al. 2009). Moreover, germ-line cysts in hirudinean species have consistent architecture; each germ cell is connected via one cytoplasmic bridge to a central cytoplasmic core, a cytophore. The cytophore ensures cytoplasmic continuity between the nurse cells and growing oocytes (Świątek et al. 2009).

In all species of the oligochaetous clitellates, the ovaries are small, sac-like structures covered only by a thin layer of peritoneum, and not enclosed within an ovisac (Eckelbarger 2006). Oogenesis in oligochaete species is generally regarded as panoistic; i.e. all female germ cells, except for those that degenerate, become oocytes, and the occurrence of nurse cells (with some exceptions, see below) has not been reported (Jamieson 1981, 1992, 2006; Eckelbarger 2006). However, germ-cell cysts are formed during early oogenesis in such oligochaetous clitellates as Eisenia foetida (Savigny, 1826) (Chapron and Relexans 1971a, b) and Enchytraeus albidus Henle, 1837 (Dumont 1969), and it is believed that all female germ cells have the potential to become egg cells. On the other hand, Paschma (1962) and recently Siekierska (2003) have described nurse cells in the ovaries of E. albidus and Dendrobaena veneta (Rosa, 1886). This suggests that meroistic oogenesis occurs also in oligochaetous clitellates.

The aim of the present work was to investigate the structure of ovaries and the course of oogenesis in non-hirudinean Clitellata at the ultrastructural level. We determined the mode of oogenesis occurring in oligochaetous clitellates and compared it with that in the well-studied Euhirudinea. The present paper is devoted to Tubificinae.

Tubificinae belongs to a large group of small, aquatic oligochaetous clitellates (Erséus 2005). The ultrastructure of their ovaries as well as their oogenesis is completely unknown; previous studies concentrated on egg development only (see Shimizu 1996 and references herein). In the present paper, we use light, fluorescent, and transmission electron microscopy to show that in representatives of the three genera studied (Tubifex, Potamothrix, and Limnodrilus) the germ-line cysts are formed during early oogenesis, and that their organization is broadly similar to the ovary cords found within euhirudinean ovaries.

\section{Materials and methods}

The following species were studied: Tubifex tubifex (Müller, 1774), Limnodrilus claparedeanus (Ratzel, 1868) and Potamothrix bavaricus (Oschmann, 1913). Specimens of $T$. tubifex were bred under laboratory conditions; the other species were collected from small ponds and streams in southern Poland in 2008-2009.

\section{Light and electron microscopy}

The specimens of all of the species studied were initially fixed with $2.5 \%$ glutaraldehyde in $0.1 \mathrm{M}$ phosphate buffer ( $\mathrm{pH} 7.4)$, then dissected. Segments with gonads were fixed in $2.5 \%$ glutaraldehyde in the same buffer at room temperature for several days. After washing in phosphate buffer, the material was postfixed for $2 \mathrm{~h}$ in $1 \% \mathrm{OsO}_{4}$ in the same buffer, dehydrated in a graded series of ethanol replaced by acetone and then embedded in Epon 812 (Fullam Inc., Latham, NY, USA). Semithin sections $(0.8 \mu \mathrm{m}$ thick) stained with methylene blue were examined under an Olympus BX60 microscope equipped with a DP12 digital camera and AnaliSIS 3.2 (Soft Imaging System) software. Ultrathin sections $(80 \mathrm{~nm})$ were cut on a Leica ultracut UCT ultramicrotome. After contrasting with uranyl acetate and lead citrate, the sections were examined using a Hitachi H500 electron microscope at $75 \mathrm{kV}$. Additionally, dissected gonads of $T$. tubifex, L. claparedeanus, and P. bavaricus were fixed in $4 \%$ formaldehyde (freshly prepared from paraformaldehyde) in PBS (phosphate buffered saline, $\mathrm{NaCl}, 137 \mathrm{mM} ; \mathrm{KCl}$, $2.7 \mathrm{mM}$; $\mathrm{Na}_{2} \mathrm{HPO}_{4} 8 \mathrm{mM}$; $\mathrm{KH}_{2} \mathrm{PO}_{4}, 1.5 \mathrm{mM}, \mathrm{pH}$ 7.4) for $30-40 \mathrm{~min}$ at room temperature and analyzed under an Olympus BX60 microscope equipped with Nomarski differential interference contrast. 
Fluorescence microscopy

Dissected ovaries of all of the species studied were fixed in $4 \%$ formaldehyde in PBS for 30-40 min at room temperature and stained with DAPI (4',6-diamidino-2-phenylindole dihydrochloride) $(1 \mu \mathrm{g} / \mathrm{ml}$; Sigma, St. Louis, MO) in PBS for $45 \mathrm{~min}$ at room temperature in darkness. To detect the F-actin distribution within the germ-line cysts, the dissected ovaries of T. tubifex, after fixation in $4 \%$ formaldehyde in PBS for 30-40 min at room temperature, were stained with rhodamine-conjugated phalloidin $(2 \mu \mathrm{g} / \mathrm{ml}$, Sigma) for $45 \mathrm{~min}$ in darkness, washed again in PBS, and additionally stained with DAPI $(1 \mu \mathrm{g} / \mathrm{ml})$ for $30 \mathrm{~min}$ in darkness. In addition, the dissected ovaries of T. tubifex and L. claparedeanus after fixation in $4 \%$ formaldehyde (for 30-40 min) were washed in PBS, dehydrated in a graded ethanol series, then infiltrated and embedded in Histocryl resin (London Resin Company Ltd, Basingstoke, Hampshire, England). The Histocryl sections (1 $\mu \mathrm{m})$ were stained in a mixture of DAPI $(1 \mu \mathrm{g} / \mathrm{ml})$ and iodium propide ( $1 \mu \mathrm{g} / \mathrm{ml}$; Sigma) at a ratio 1:1 for $30 \mathrm{~min}$ in darkness. Whole-mounted preparations and Histocryl sections were examined under an Olympus BX60 epifluorescence microscope equipped with appropriate filters.

\section{Results}

The following descriptions refer to all species being studied unless indicated otherwise.

\section{Gross morphology of the ovaries}

The ovaries are paired structures, conically shaped, with the narrow end connected to the intersegmental septum between segments X and XI. Each ovary is joined to the septum via a thin ligament (Fig. 1a), whereas the broad end of the ovary extends freely into the coelom of segment XI. The ovaries are composed of cysts of germ-line cells (see below) enveloped by a layer of elongated follicular cells, which are almost undetectable on whole-mounted preparations (Fig. 1a, b), but their nuclei are visible on the semithin sections (Fig. 1c-d). The germ cells in the ovaries are represented by oogonia, undifferentiated germ cells united into cysts (cystocytes), oocytes at different stages of oogenesis (from the onset of oogenesis to early vitellogenic ones) and nurse cells (Fig. 1a-d). The oocytes that intensively absorb the yolk (vitellogenic ones) have lost contact with the cytophore and float freely in the coelom. Vitellogenic oocytes and oocytes that have completed vitellogenesis, i.e. oocytes arrested in meiotic metaphase I, are in close contact with blood vessels and the coelomic epithelium (Fig. 2c).
The ovaries are evidently polarized, i.e. their narrow end connected to the septum contains oogonia (zone I), just below there are undifferentiated germ cells united into cysts (zone II), and in the middle and the outermost part (zone III) of the ovaries the germ cells in cysts are diversified into several growing oocytes and numerous nurse cells (Figs. 1a-d; 2a, b, d). It is worth noting here that oocytes usually grow in a linear arrangement on one side of the ovary only (Figs. 1a-c; 2a, b).

\section{Germ-line cysts}

Like all of the clitellate annelids studied so far (see Świątek et al. 2009 and references herein), the germ cells in all of the species studied are united into syncytial cysts. The pattern of the organization of the cysts is also the same as in other Clitellata. Each germ cell in a cyst has only one stable cytoplasmic bridge (usually referred to as a ring canal) connecting it to a central, anuclear cytoplasmic core, the cytophore (Figs. 1b-d; 2a, b, e, f; 3a-g). Germ-line cysts are formed before germ cells enter meiosis. The last mitotic divisions of oogonia are not followed by full cytokineses; instead the cleavage furrow is stabilized and forms a broad cytoplasmic channel, a ring canal (Fig. 3a-f). The formation of germ-cell cysts has not been observed in the Tubificinae studied; however, the organization of the cysts suggests that they develop in the same manner as in other clitellate annelids (see Świątek et al. 2009). In zones I and II of the ovary, the germ cells within a cyst (cystocytes) are morphologically identical (Figs. 2d; 3a, b). All germ cells in this region of the ovary enter meiotic prophase I; the synaptonemal complexes are easy to see within the nuclei of these cells (Fig. 3a). Beneath this region the majority of germ cells cease meiosis, their nuclei return to an interphase organization of chromatin, and these cells become nurse cells (Figs. 2a, b, d-f; 3b-d). Several cells continue meiosis and grow; their nuclei contain meiotic chromosomes in the form of lampbrush chromosomes and start to grow as oocytes (Fig. 1c, d).

Nurse cells and oocytes

There are hundreds or even thousands of nurse cells in each ovary (Figs. 1a-d; 2a, b, d-f). They are slightly bigger than the undifferentiated germ cells (Figs. 1a; 2d). Like every germ cell, each nurse cell possesses one ring canal connecting it to a central cytoplasmic core (cytophore) (Fig. 3c, d). As a result, germ cells are arranged around the centrally located cytophore (Figs. 1b-d; 2a, b, e, f). The nuclei of the nurse cells have prominent nucleoli (Figs. 1c, $\mathrm{d} ; 2 \mathrm{a}, \mathrm{b}, \mathrm{d}-\mathrm{f} ; 3 \mathrm{c}, \mathrm{d})$, and the nuclear envelope of the nurse cells is usually irregular and equipped with nuclear pores (Fig. 3c, d). Accumulations of unbounded granulo-fibrillar 

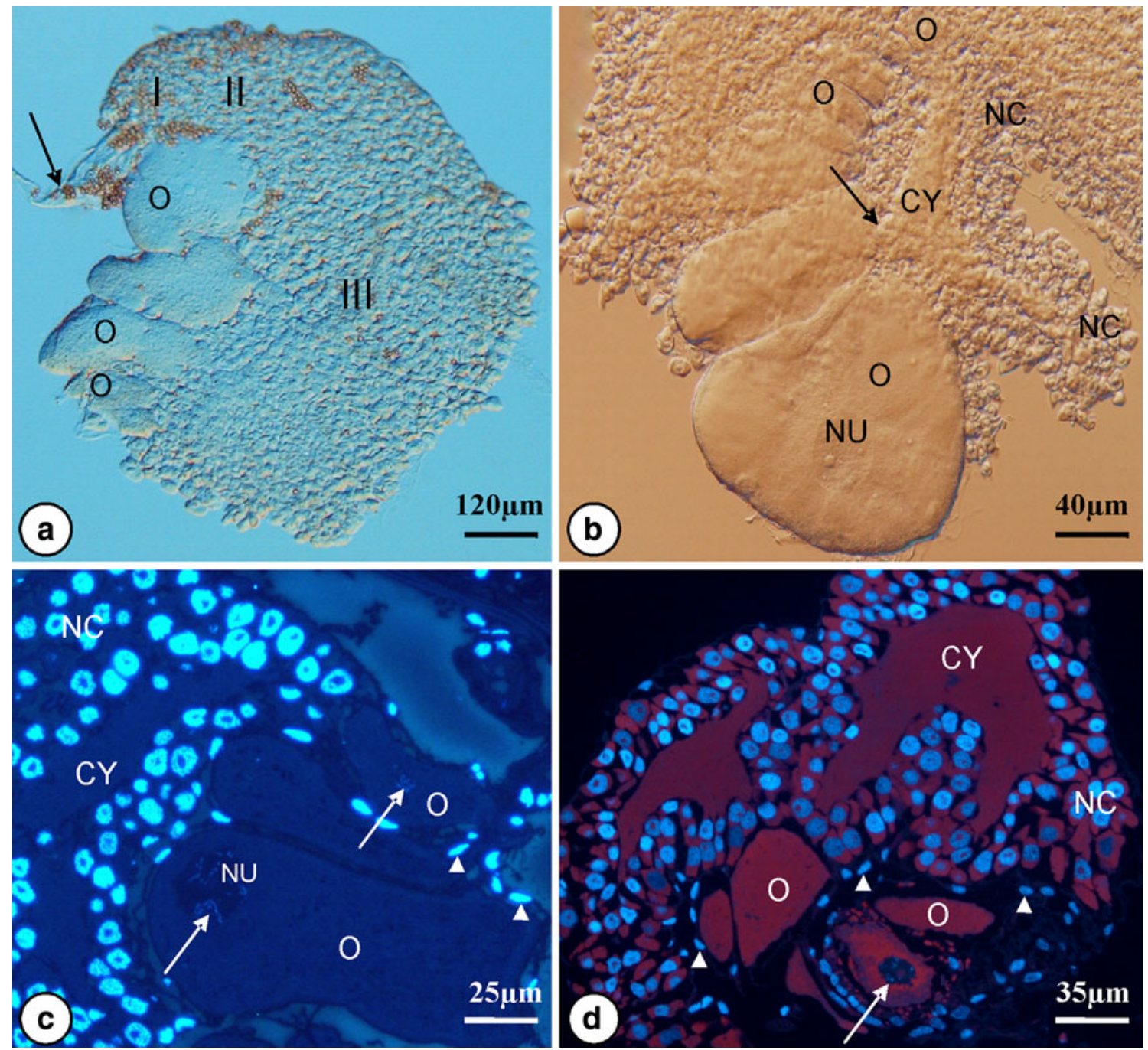

Fig. 1 General organization of ovaries in Tubifex tubifex. a The narrow end of the ovary is connected to the septum via a ligament (arrow); distinguished ovary zones are marked $(I, I I, I I I)$. Oocytes $(O)$ grow in a linear arrangement on the one side of the ovary only. Whole-mounted preparation, Nomarski interference contrast (DIC). b The outermost part of the ovary; the row of growing oocytes $(O)$, prominent cytophore $(C Y)$, and numerous small nurse cells $(N C)$ are

clearly visible; $N U$ oocyte nucleus; arrow points to the connection between the growing oocyte and the cytophore. Whole-mounted preparation, DIC. c,d Sections through the IIIrd zone of the ovary. $C Y$ cytophore, $N C$ nurse cells, $O$ oocytes; within oocyte's nuclei $(N U)$ meiotic chromosomes are visible (arrows); arrowheads mark nuclei of follicular cells. Fluorescence microscopy, Histocryl semithin sections stained with DAPI (c) and with a mixture of DAPI and IP (d)

material (interpreted as nuage material) associated with mitochondria are usually observed in the perinuclear cytoplasm (Fig. 3d). The cytoplasm of the nurse cells is enriched with ribosomes, mitochondria, and cisternae of RER; some Golgi complexes and lipid droplets can also be found (Fig. 3c, d). Degenerating nurse cells have rarely been observed within the ovaries (not shown); probably in the basal end of the ovary the nurse cells lose contact with the cytophore and are released from the ovary into the coelom or are completely removed during gonad regression (see below).

The youngest, early previtellogenic oocytes are hardly distinguishable from nurse cells; the distinction is easier to

see when the oocytes become slightly bigger than the nurse cells (Figs. 1b, c; 2a, b). Oocytes, in contrast to nurse cells, have meiotic (lampbrush) chromosomes within their nuclei, and their plasma membrane forms short microvilli (Figs. 1c, d; 3e). The nuclei of previtellogenic oocytes have irregular outlines, and each contains a prominent nucleolus and occupies the cell center (Figs. 2f; 3e). As oogenesis progresses the oocyte nuclei become more spherical and move eccentrically (Figs. 1b-d; 2a, b). Within the nuclei of vitellogenic oocytes, small electron-dense nuclear bodies, meiotic chromosomes and a nucleolus with numerous vacuoles occur (Figs. 1b; 4a). Each previtellogenic/early vitellogenic oocyte is still connected to the cytophore via a 
broad ring canal (Figs. 1b; 2f; 3f). Numerous cell structures such as mitochondria, short ER cisternae, and lipid droplets can be seen passing the bridge (Fig. 3f). Vitellogenic oocytes lose contact with the cytophore and float freely in the coelomic fluid (Fig. 2c). Such vitellogenic oocytes as well as oocytes arrested in meiotic metaphase I are in immediate contact with blood vessel walls (Figs. 2c; 4b, c) and are covered with coelomic epithelia (Figs. 2c; 4b, c). The growing oocytes gather a vast amount of yolk material in the form of electron-dense protein spheres, glycogen accumulations, and lipid droplets (Figs. 2a-c; $4 \mathrm{a}-\mathrm{c}$, e). Cortical granules have never been observed in the cortical ooplasm. As has already been mentioned, at the onset of oogenesis the ooplasma forms microvilli (Figs. 3e; 4d), the microvilli become shorter and shorter as oogenesis progresses, and as a result the oocytes arrested in meiotic metaphase I have an almost smooth oolemma (Fig. 4e). The vitelline envelope is poorly developed; it has the form of a thin layer of filamentous material deposited between microvilli (Fig. 4c-d).

Ring canals and the cytophore

Undifferentiated germ cells, nurse cells, and growing oocytes are asymmetrical, with one pole equipped with a ring canal connecting them to a cytophore for as long as they are connected to the cytophore (Fig. 3a-f). The ring canal wall of undifferentiated germ cells $(\sim 1.5 \mu \mathrm{m}$ in diameter) is composed of two rims: an outer one in the form of a thickening of the cell membrane and an inner one composed of a layer of fibrous, electron-dense material (Fig. 3a, b). Rhodamine-conjugated phalloidin staining showed that F-actin is distributed within the walls of the ring canals (not shown). Inside the ring canals connected to the initial cytophore, fine granulo-fibrillar material and cell organelles such as the cisternae of ER and mitochondria are observed (Fig. 3a, b). In nurse cells and previtellogenic oocytes, the ring canals are broader; their maximal measured diameter was $1.8 \mu \mathrm{m}$ in the case of nurse cells, and $9 \mu \mathrm{m}$ in the case of growing oocytes (Fig. 3c-f). The cytoplasm filling in the ring canals does not differ from the cell cytoplasm; such cell organelles as mitochondria, cisternae of ER, Golgi complexes and even small lipid droplets were found within them (Fig. 3c-f). A difference was observed in the structure of the ring canal wall; the length of the ring encircling the intercellular channel in nurse cells and young oocytes was usually very short (Fig. 3f) or was completely lacking as was observed in the nurse cells of P. bavaricus (Fig. 3c, d). When the oocytes accumulate yolk and grow considerably, they are no longer connected to the cytophore. Ring canals between vitellogenic oocytes and cytophore have never been observed (Fig. 2c).
Initially, in zones I and II of the ovary, the cytophore has the form of thin cytoplasmic strands stretched between the germ cells and is almost undetectable at the light microscopy level (Fig. 2d). Electron microscopy reveals that such a primordial cytophore contains typical cell organelles such as mitochondria and ER cisternae (Fig. 3a, b). When nurse cells and oocytes appear, the cytophore enlarges and occupies the central position in the cyst (Figs. 1b-d; 2a, b, $\mathrm{e}, \mathrm{f}$ ). The fully formed cytophore contains typical cell organelles (except nuclei), i.e. ribosomes, mitochondria, Golgi complexes, ER cisternae, and reserve material in the form of lipid droplets (Fig. 3c-g). Usually, prominent accumulations of cytoskeletal elements (microtubules) were observed within the cytophore (Figs. 2b, e, f; 3g).

\section{Follicular cells}

The entire ovary together with previtellogenic and early vitellogenic oocytes connected to the cytophore are enveloped by a layer of peritoneal (follicular) cells. Additionally, follicular cells are distributed between germ cells within a cyst (Figs. 1c, d; 4f). Because these cells are in immediate contact with germ cells, they will be referred to as follicular cells. The follicular cells enveloping ovaries are extremely elongated; their nuclei are visible on sections only (Fig. 1c, d). The follicular cells limiting previtellogenic/early vitellogenic oocytes show a characteristic feature: their plasma membrane folds and forms deep invaginations which eventually seem to form small channels throughout their cytoplasm (Fig. 4d). Initially, the vitellogenic oocytes and oocytes arrested in meiotic metaphase I float freely in the segment lumen and are not covered by any envelope; then, they are in close contact with blood vessels and are covered by two layers of coelomic epithelium equipped with muscle cells (Figs. 2a-c; 4b, c).

\section{Discussion}

Ovaries in the species studied resemble the ovary cords in Hirudinea

Solid cords (ovary cords) composed of cysts of gem cells enveloped by somatic cells occur within the ovisacs of Euhirudiea with only one known exception (Piscicolidae species) (Fernández et al. 1992; Spałek-Wołczyńska et al. 2008; Światek 2008). The morphology of the ovary cords is group specific. In several representatives of glossiphoniids, there are one or two long and convoluted cords in each ovisac, and these cords are non-polarized; i.e. no zones with consecutive stages of oogenesis can be found within ovary cords. Oogenesis is synchronous in the entire cord, and after the release of oocytes to the hemocelomic fluid 


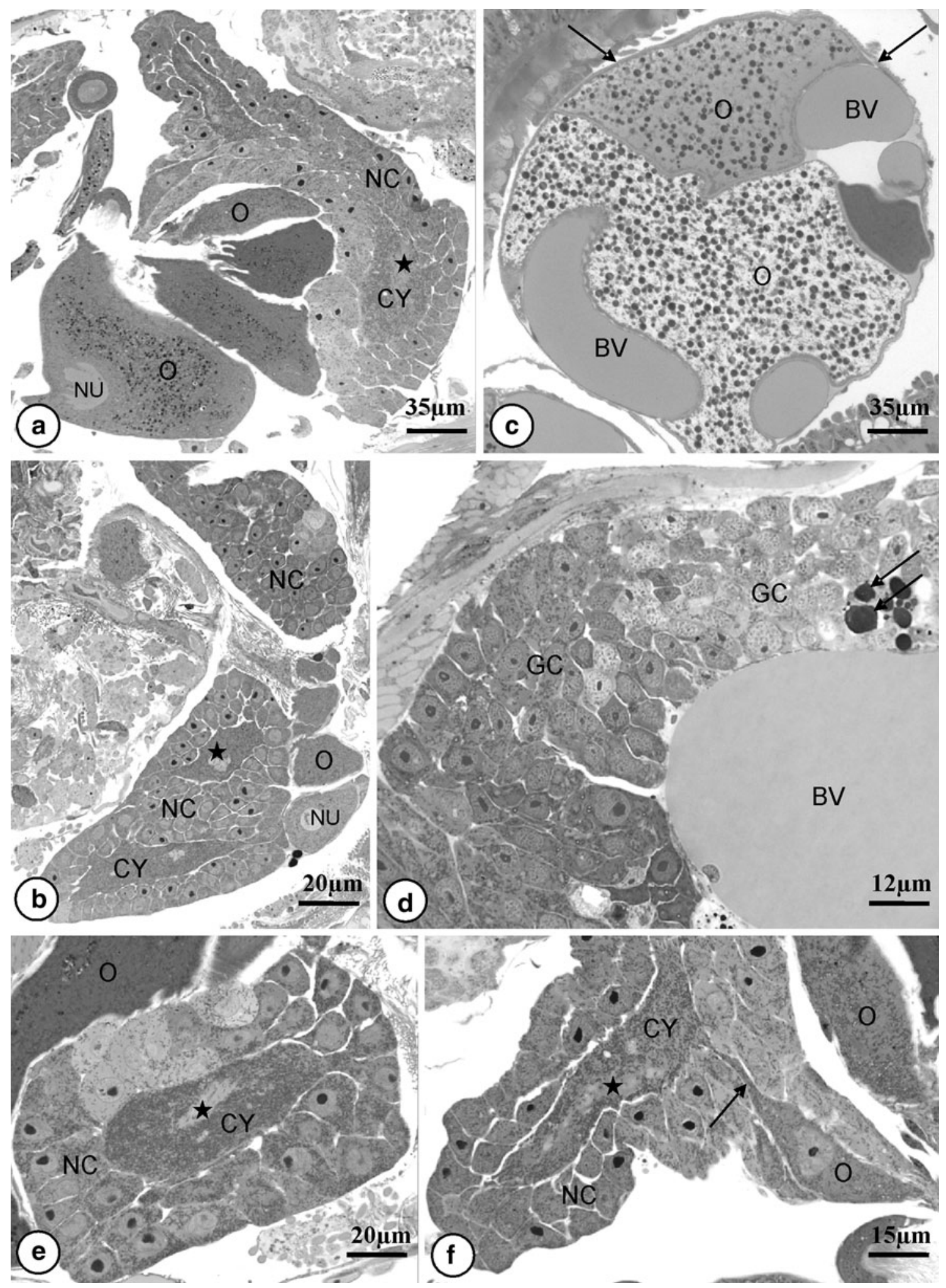

the ovary cords degenerate (Fernández et al. 1992; Światek 2005b, 2006). In Hirudo medicinalis Linnaeus, 1758, Hirudo troctina Johnson, 1816, Limnatis nilotica (Savigny, 1822) and Haemopis sanguisuga (Linnaeus, 1758), there are also two long and convoluted cords in each ovisac. They are evidently polarized, their club-shaped end contains one huge somatic cell (apical cell) and mitotically dividing oogonia, and while oocytes grow in the middle 
4 Fig. 2 a, b Organization of ovaries in Limnodrilus claparedeanus. Growing oocytes $(O)$, nurse cells $(N C)$, and cytophore $(C Y)$ with accumulations of cytoskeletal elements (stars) are visible; $N U$ oocyte nuclei. c Potamothrix bavaricus. Vitellogenic oocytes $(O)$ are in close contact with blood vessels $(B V)$ and are surrounded by coelomic epithelium (arrows). d Zones I and II of the Tubifex tubifex ovary. Within this part of the ovary, the germ cells $(G C)$ are undifferentiated, and all are in meiotic prophase I. Some degenerating cells (arrows) are also visible; $B V$ blood vessel. e, f Details of the organization of a germ-line cyst in L. claparedeanus. The cytophore $(C Y)$ occupies the cyst center, whereas the nurse cells $(N C)$ and oocytes $(O)$ are located peripherally and are connected to the cytophore via ring canals (arrow). Within the cytophore, accumulations of cytoskeletal elements are visible (stars). a-f Light microscopy, Epon semithin sections stained with methylene blue

part of the cord, the distal end contains only degenerating cells (Świątek 2008; Ben Ahmed et al. 2010). On the other hand, in Erpobdella octoculata (Linnaeus, 1758), there are 5-7 short ovary cords with a conical part also equipped with an apical cell and mitotically dividing oogonia (Świątek et al. 2010). Despite the morphological differences, the ovary cords are always formed from germ-cell cysts with a consistent pattern of organization. Each germ cell bears only one ring canal connecting it to the anuclear cytophore (Świątek 2008; Świątek et al. 2009). The cytophore may be huge and centrally located as has been found in many glossiphoniids (Fernández et al. 1992; Świątek 2005b, 2006) or may be poorly developed in the form of thin cytoplasmic strands as was found in E. octoculata (Świątek et al. 2010).

In all of the tubificoid Naididae species studied, the ovaries are short, conically shaped, with the narrow end connected to the intersegmental septum. The ovaries are polarized; their narrow end contains oogonia and undifferentiated germ cells united into cysts, while developing primary oocytes can be found in the middle and at the outermost part of the ovary. Generally, such an organization is broadly similar to the polarized ovary cords found in H. medicinalis, H. troctina, L. nilotica, $H$. sanguisuga and E. octoculata; but we have found no apical cell or zone with degenerating germ cells in the ovaries of the tubificin species studied. On the other hand, the prominent cytophore located in the cyst center found in the Tubificinae studied strongly resembles the organization of the ovary cords in glossiphoniids (Fernández et al. 1992; Świątek 2005b, 2006). Some details of oogenesis, e.g. the poorly developed vitelline envelope or follicular cells equipped with intracellular canals, are similar in the species studied and in Euhirudinea. Alongside these similarities are some differences; e.g. in contrast to hirudineans, Tubificinae ovaries are not enclosed within ovisacs, and their vitellogenic oocytes and oocytes arrested in meiotic metaphase I are in close contact with blood vessels.

There are several older studies devoted to the organization of the ovary and oogenesis in non-hirudinean
Clitellata, such as those by D'Angelo (1965) and Bondi and Facchini (1972) on Branchiobdella pentodonta Whitman, 1882 (Branchiobdellida); Paschma (1962) and Dumont (1969) on Enchytraeus albidus (Enchytraeidae); Lechenault (1968) and Chapron and Relexans (1971a, b) on Eisenia foetida (Lumbricidae); and only one modern study on another lumbricid species, Dendrobaena veneta (Siekierska 2003). In B. pentodonta, E. foetida and D. veneta, the ovaries are polarized, and three distinct zones have been distinguished; however, only in D. veneta have nurse cells been described and a meroistic mode of oogenesis suggested (Siekierska 2003). In D. veneta, ovary zone I is comprised of oogonia, zone II contains nurse cells and previtellogenic oocytes, and in zone III vitellogenic oocytes and a few nurse cells occur (Siekierska 2003). Such a pattern of organization is similar to the one presented in this paper. The main difference is the organization of the cytophore. In the representatives of Tubificinae studied, the cytophore is a prominent structure; in D. veneta it is poorly developed and has the form of extremely thin, elongated cytoplasmic strands (Siekierska 2003). A detailed comparison of the organization of ovaries and the course of oogenesis in the Tubificinae studied and in D. veneta and Euhirudinea is presented in Table 1.

To sum up, the ovaries in the genera studied are composed of germ-line cysts surrounded by follicular cells. Their general organization resembles the polarized ovary cords found in some euhirunidid species such as $H$. medicinalis, H. troctina, L. nilotica, H. sanguisuga and E. octoculata; on the other hand, the occurrence of a prominent cytophore resembles the ovary cords found in glossiphoniids. To a lesser extent, the ovaries found in the Tubificinae genera studied are similar to those found in D. veneta. The pattern of the organization of germ-line cysts in Tubificinae is also identical to that in all clitellate annelids studied to date.

\section{Evidence for meroistic oogenesis in the species studied}

Interconnected groups of germ cells (germ-cell cysts) are a conserved phase of animal gametogenesis, especially during spermatogenesis (Guo and Zheng 2004). During oogenesis, however, germ-cell cysts (1) seem to be entirely absent in some species (Pepling et al. 1999); or (2) they may function for a short period of time (they disappear before the germ cells enter meiosis), as has been shown in many invertebrate and vertebrate species (see Büning 1994; Kloc et al. 2004; Pepling and Spradling 1998; Pepling et al. 1999 for examples); or (3) germ-line cysts function into the advanced stages of oogenesis (at least until late previtellogenesis), as is known from ovaries of many species (see Büning 1994; de Cuevas et al. 1997; Pepling et al. 1999; Matova and Cooley 2001; Świątek et al. 2009 for examples). In the first two scenarios, 

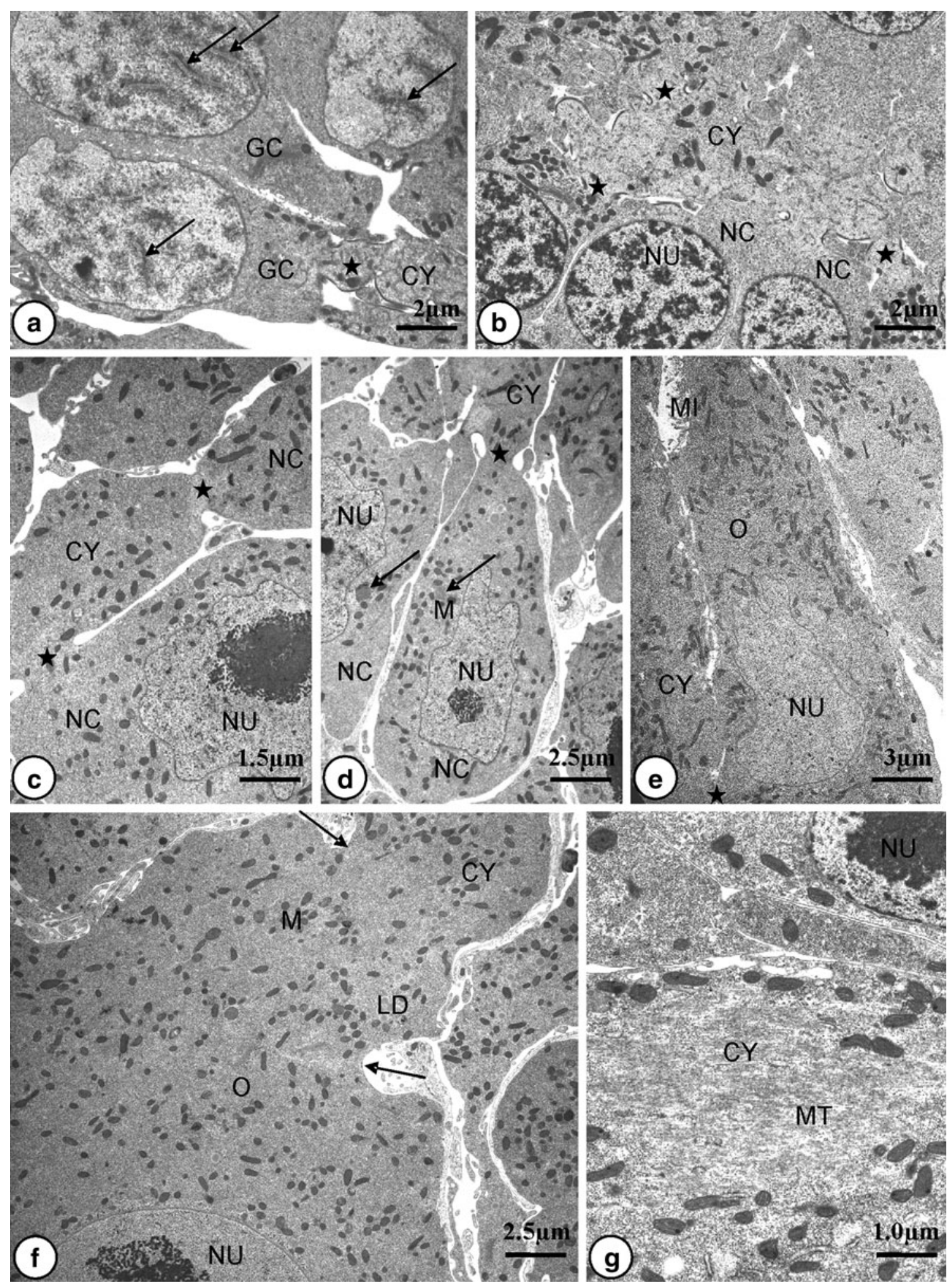

oogenesis is panoistic; i.e. each oogonium has the potential to become an oocyte. In the third scenario, oogenesis is meroistic; i.e. the ultimate fate of female germ cells is different: usually, the majority of cells become nurse cells, while the rest continue meiosis and become oocytes. Nurse cells are usually polyploid and supply the growing oocyte(s) with macromolecules (mainly mRNAs, rRNAs) and cell organelles, and finally they may be eliminated by programmed cell death (de Cuevas et al. 1997, Matova and Cooley 2001; McKearin et al. 2005; Ong and Tan 2010). 
4 Fig. 3 a Zone I of Limnodrilus claparedeanus ovary. All germ cells $(G C)$ enter meiosis prophase I; synaptonemal complexes (arrows) are visible. Germ cells are connected to the initial cytophore $(C Y)$ via ring canals (star). b Zones II/III of L. claparedeanus ovary. The nurse cells $(N C)$ withdraw from meiosis; their nuclei $(N U)$ show an interphase organization of chromatin. Each nurse cell is connected to the cytophore $(C Y)$ via a ring canal (stars). c, d Zone III of Potamothrix bavaricus ovary. Nurse cells $(N C)$ are still connected to the cytophore $(C Y)$ via ring canals (stars). Note nuage accumulations (arrows) associated with mitochondria $(M) ; N U$ nuclei of nurse cells. e $L$. claparedeanus. Early previtellogenic oocyte $(O)$ connected to the cytophore $(C Y)$ via a ring canal (star). Oocyte has an irregularly shaped nucleus $(N U)$; its oolemma forms microvilli $(M I)$. f A fragment of a previtellogenic oocyte $(O)$ and cytophore $(C Y)$ in $P$. bavaricus. The ring canal is broad (arrows); mitochondria $(M)$ and lipid droplets $(L D)$ can be seen passing the ring canal; $N U$ oocyte nucleus. $\mathbf{g}$ Detail of cytophore $(C Y)$ structure in L. claparedeanus. An accumulation of microtubules $(M T)$ is visible; $N U$ nurse cell nucleus. a-g Transmission electron microscopy (TEM)

It is known that germ-line clusters are also formed in some species of oligochaetous clitellates. Cysts of interconnected oogonia and primary oocytes have been found in Eisenia foetida (Chapron and Relexans 1971a, b) and Enchytraeus albidus (Dumont 1969); however, the authors did not notice any nurse cells, and they believed that each germ cell in a given cluster has the potential to become an oocyte. Such a scenario resembles the above-mentioned examples of panoistic oogenesis (the second scenario), and it is generally believed that in oligochaetous clitellates there are no nurse cells and that the ovaries are in fact panoistic (Jamieson 1981, 1992, 2006; Eckelbarger 2006). In addition to the present paper, there are only two studies describing nurse cells in oligochaetous clitellates and suggesting the meroistic mode of oogenesis. At the light microscopy level, Paschma (1962) described the organization of ovaries and oogenesis in E. albidus and found 15 nurse cells and one oocyte in each 16-cell cyst (this report contradicts observations by Dumont (1969), who found only an 8-cell cyst of germ cells showing the same potential to become functional gametes). As mentioned earlier, Siekierska (2003) described the ovaries of the earthworm $D$. veneta at the ultrastructural level and found two populations of germ cells: numerous nurse cells and less abundant primary oocytes. Both cell categories have ring canals connecting them to thin strands of cytoplasm resembling an elongated cytophore.

Here, we clearly show that in representatives of three tubificin genera, cysts of interconnected germ cells are formed during early oogenesis. The germ cells form syncytial clusters until later stages of oogenesis, and the oocytes detach from the cytophore during late previtellogenesis/early vitellogenesis. Ultrastructural studies also showed that cytoplasm flows through ring canals together with cell organelles such as ribosomes, mitochondria, short ER cisternae, and lipid droplets, and it appears to be transported from nurse cells via the cytophore toward growing oocytes. Moreover, only oocytes have meiotic organization of their chromatin (lampbrush chromosomes); the rest of the female germ cells cease meiosis, and their chromatin within nuclei has interphase organization. Unfortunately, we still have no direct proof for macromolecule and/or cell organelle transport from nurse cells toward oocytes, and we were not able to determine the final fate of nurse cells. The nurse cells probably are removed from the ovary during gonad regression, as is typical for Tubificinae after the cocoon-laying period (Casellato et al. 1987). Taking into account the above arguments and the identity between the organization of the ovaries in the species studied and that of meroistic ovaries of hirudinean species (in leeches, transport of RNA from nurse cells via the cytophore toward the growing oocytes was demonstrated in an autoradiographic study by Aisenstadt et al. 1967), we suggest that oogenesis in species of the Naididae studied should be regarded as meroistic. We also suggest that the main function of the nurse cell in meroistic ovaries of tubificin species is to supply the growing oocytes with macromolecules (RNAs) and cell organelles. The nurse cells in species of the Tubificinae apparently are not engaged in yolk formation. The oocytes mainly gather yolk after detaching from the cytophore, when they are associated with blood vessels, and as was shown in some polychaetous annelid species such an association may be connected with yolk uptake (Eckelbarger 1983).

On the other hand, the possibility that all female germ cells have the potential to become an egg cell (panoistic oogenesis) cannot be excluded. In such a case, there is asynchrony in female germ-cell development in a given cyst; only some oocytes grow and are released at a time. The rest of the potential oocytes have no chance to grow due to limited resource allocation and subsequent regression of the gonad. Studies into macromolecule transport, diversification of cell fates within cysts, and the level of nurse cell ploidy in clitellate annelids should finally resolve that problem.

Is meroistic oogenesis characteristic for all clitellate annelids?

We know from many studies that the formation of a germline syncytial cyst with a cytoplasmic core is the conserved phase of spermatogenesis and oogenesis in clitellate annelids (for references, see Ferraguti 1999; Jamieson 2006; Świątek et al. 2009). The meroistic mode of oogenesis is characteristic for Euhirudinea (Świątek 2008), whereas for oligochaetous clitellates the panoistic mode of oogenesis has been suggested (Jamieson 1981, 1992, 2006; Eckelbarger 2006). Taking together the present paper, observations made by Paschma (1962) on E. albidus (Enchytraeidae) and Siekierska (2003) on D. veneta (Lumbricidae) and our preliminary results on the organization of ovaries in 

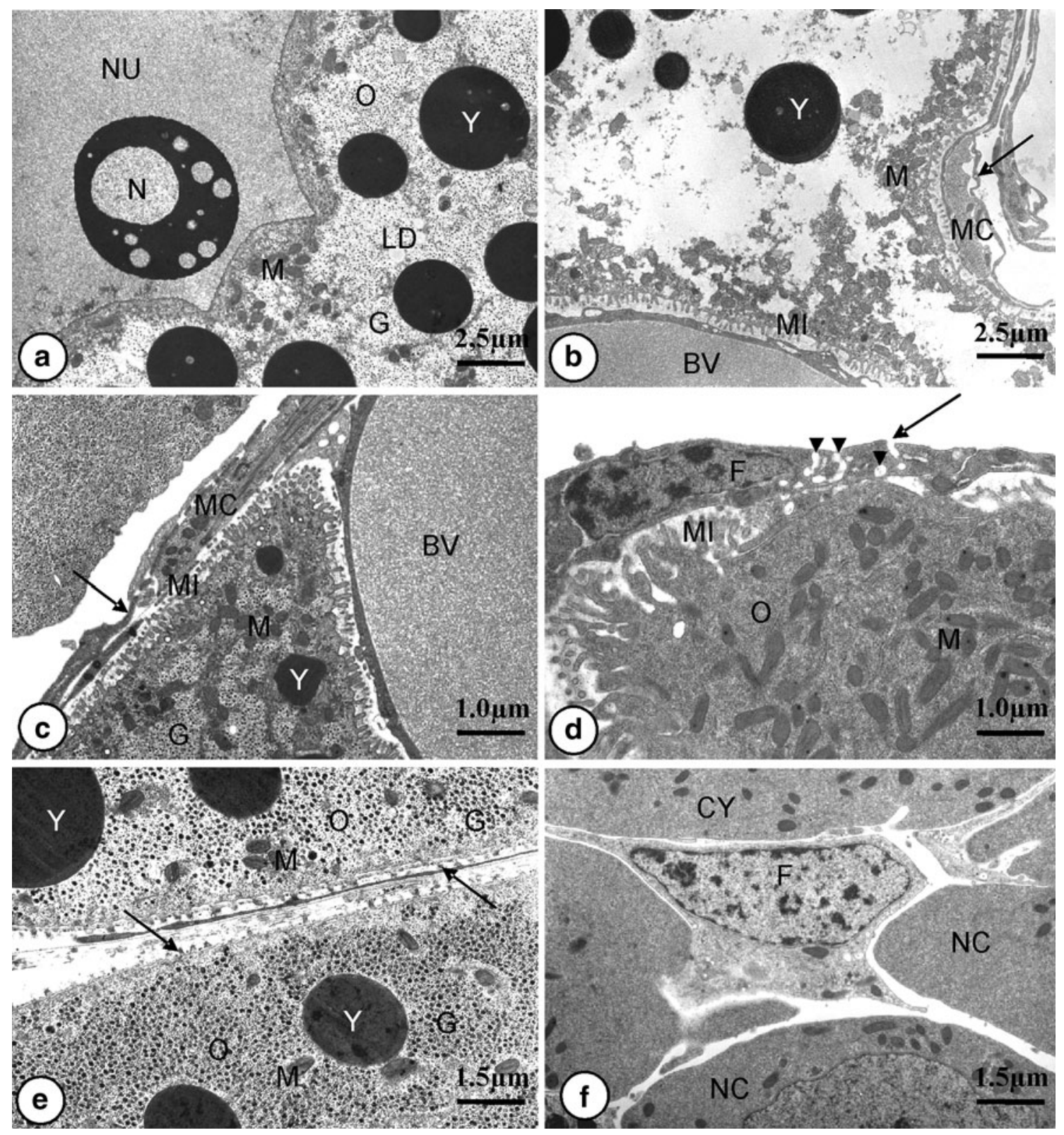

Fig. 4 a Fragment of a vitellogenic oocyte nucleus $(N U)$ and ooplasm $(O)$ of Limnodrilus claparedeanus. A prominent nucleolus $(N)$ with vacuoles occurs within the oocyte nucleus. The ooplasm is filled with yolk spheres $(Y)$, glycogen granules $(G)$, and small lipid droplets $(L D) . M$ Mitochondria. b, $\mathbf{c}$ Vitellogenic oocytes of Potamothrix bavaricus (b) and L. claparedeanus (c) are enveloped by coelomic epithelia (arrows) associated with muscle cells $(M C)$ and are in immediate contact with blood vessels $(B V)$. $G$ Glycogen accumulations, $M$ mitochondria, $M I$ microvilli with a poorly developed vitelline envelope, $Y$ yolk spheres, $\mathbf{d}$ Detail of $L$. claparedeanus

representatives of Lumbriculidae, Branchiobdellida and Acanthobdella peledina, where we found germ-line cysts with nurse cells and primary oocytes (P. Świątek et al., unpublished results), we suggest that meroistic oogenesis is more widespread within Clitellata than earlier suspected. late previtellogenic oocyte $(O)$ enveloped by follicular cells $(F)$. Note the invaginations of the follicular cell plasma membrane (arrow) forming deep intracellular channels (arrowheads). $M$ Mitochondria, $M I$ microvilli. e Cortical ooplasm of two oocytes $(O)$ of $L$. claparedeanus arrested in meiotic metaphase I. Oolemma forms short microvilli (arrows); ooplasm is filled with a vast amount of glycogen granules $(G)$; yolk spheres $(Y)$ and mitochondria $(M)$ are also visible. f A follicular cell $(F)$ within the ovary of $P$. bavaricus, $C Y$ Cytophore, $N C$ Nurse cells. a-f TEM

However, the ovary architecture and course of oogenesis are still completely unknown in some clitellate annelids (e.g. Glossoscolecidae, Megascolecidae), while in others they need to be redescribed (e.g. Enchytraeidae). We suggest that the formation of a germ-line cyst with a central cytoplasmic 


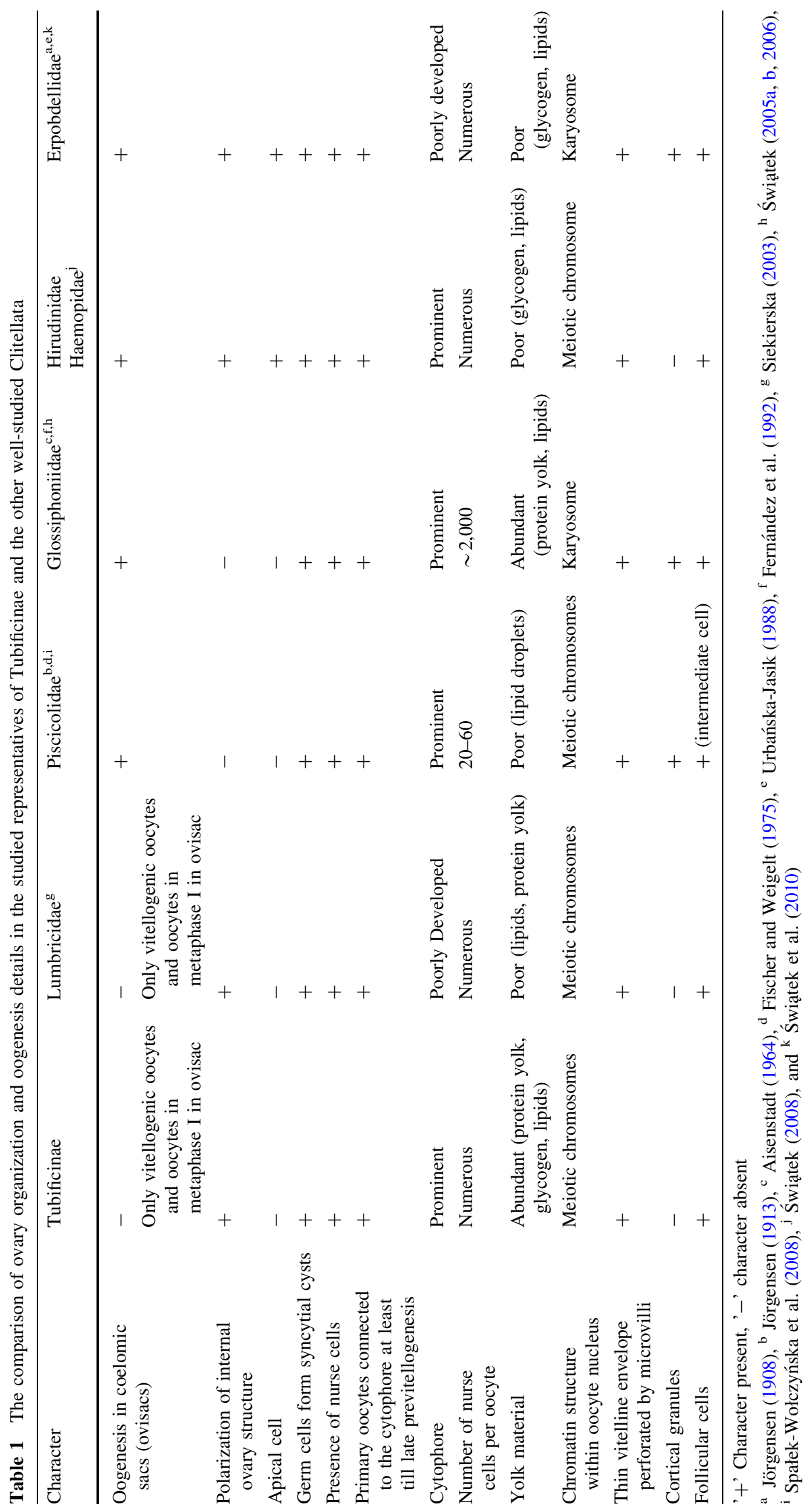


core and meroistic ovaries may be the primary characteristic of all Clitellata; in such a situation the loss of nurse cells and panoistic oogenesis should be regarded as the derived condition.

Acknowledgments This work was supported by research grant $\mathrm{N}$ N303 423636 from the Polish Ministry of Science and Higher Education.

Open Access This article is distributed under the terms of the Creative Commons Attribution Noncommercial License which permits any noncommercial use, distribution, and reproduction in any medium, provided the original author(s) and source are credited.

\section{References}

Aisenstadt TB (1964) Cytological studies of oogenesis. I. Morphology of the gonad of Glossiphonia complanata L. examined by light and electron microscopy. Citologiya 6:19-24

Aisenstadt TB, Brodsky WJ, Gazarian KG (1967) An autoradiographic study of the RNA and protein synthesis in gonads of animals with different types of oogenesis. Citologiya 4:397-406

Ben Ahmed R, Fuchs AZ, Tekaya S, Harrath AH, Świątek P (2010) Ovary cords organization in Hirudo troctina and Limnatis nilotica (Clitellata, Hirudinea). Zool Anz J Comp Zool. doi: 10.1016/j.jcz.2010.08.004

Bondi C, Facchini L (1972) Observations on the oocytes ultrastructure and vitellogenesis of Branchiobdella pentodonta Whitman. Acta Embryol Exp 2:225-241

Brinkhurst RO (1982) Evolution in the Annelida. Can J Zool 60:1043-1059

Brinkhurst RO (1984a) Comments on the evolution of the Annelida. Hydrobiologia 109:189-191

Brinkhurst RO (1984b) The position of the Haplotaxidae in the evolution of oligochaete annelids. Hydrobiologia 115:25-36

Büning J (1994) The insect ovary: ultrastructure, previtellogeneic growth and evolution. Chapman and Hall, London

Casellato S, Martinucci G, Zoja E (1987) Ultrastructural features of gametogenesis during the life cycle in Branchiura sowerbyi Beddard (Oligochaeta, Tubificidae). Hydrobiologia 155:145-154

Chapron C, Relexans JC (1971a) Connexions intercellularies et évolution nucléaire au cours de la préméiose ovocytarie. Etude ultrastructurale chez le Lombricien Eisenia foetida. C R Acad Sci Paris S D 272:3307-3310

Chapron C, Relexans JC (1971b) Ultrastructure des gonocytes primordiaux et des gonies chez l'hermaphrodite Eisenia foetida (Oligochéte Lombricidé). C R Acad Sci Paris S D 272: 2916-2919

D’Angelo L (1965) Osservazioni sull'apparato riproduttore femminile in Branchiobdella pentodonta Whitman. Arch Zool Ital 50:29-40

Damas D (1964) Structure et rôle du rachis ovarien chez Glossiphonia complanata L. (Hirudinée, Rhynchobdelle). Orgine, evolution et structure. Bull Soc Zool Fr 89:147-155

Damas D (1977) Anatomie microscopique et evolution de l'appareil genital femellle de Glossiphonia complanata (L.) (Hirudinee, Rhynchobdelle), au cours du cycle annuel. Etude histologique et ultrastructurale. Arch Zool Exp Gen 118:29-42

de Cuevas M, Lilly MA, Spradling AC (1997) Germline cyst formation in Drosophila. Annu Rev Genet 31:405-428

Dumont JN (1969) Oogenesis in the annelid Enchytraeus albidus with special reference to the origin and cytochemistry of yolk. J Morphol 129:317-344
Eckelbarger KJ (1983) Evolutionary radiation in polychaete ovaries and vitellogenic mechanisms: their possible role in life history patterns. Can J Zool 61:487-504

Eckelbarger KJ (2006) Oogenesis. In: Rouse G, Pleijel F (eds) Reproductive biology and phylogeny of Annelida. Science Publishers, Enfield, pp 23-43

Erséus C (2005) Phylogeny of oligochaetous Clitellata. Hydrobiologia 535(536):357-372

Erséus C, Ferraguti M (1995) The use of spermatozoal ultrastructure in phylogenetic studies of Tubificidae (Oligochaeta). In: Jamieson BGM, Ausio J, Justine JL (eds) Advances in spermatozoal phylogeny and taxonomy. Mémoires du Muséum d'Histoire Naturelle, Paris, pp 189-201

Fernández J, Tellez V, Olea N (1992) Hirudinea. In: Harrison FW, Gardiner SL (eds) Microscopic anatomy of invertebrates, vol 7. Annelida. Wiley-Liss, New York, pp 323-394

Ferraguti M (1999) Euclitellata. In: Adiyodi KG, Adiyodi G (eds) Reproductive biology of invertebrates, vol 9, part B. Oxford \& Ibh Publishing Co. Pvt Ltd, New Delhi, pp 125-182

Ferraguti M (2000) Euclitellata. In: Adyiodi KG, Adyiodi RG (eds) Reproductive biology of invertebrates. Wiley, Chichester, pp 165-222

Ferraguti M, Erséus C (1999) Sperm types and their use for a phylogenetic analysis of aquatic clitellates. Hydrobiologia 402:225-237

Fischer A, Weigelt KR (1975) Strukturelle Bezienhungen zwischen jungen Oocyten und somatischen Zellen bei den Anneliden Platyneris und Piscicola. Verh Dtsch Zool Ges 67:319-323

Guo GQ, Zheng GC (2004) Hypotheses for the functions of intercellular bridges in male germ cell development and its cellular mechanisms. J Theor Biol 229:139-146

Jamieson BGM (1981) The ultrastructure of the Oligochaeta. Academic Press, London

Jamieson BGM (1992) Oligochaeta. In: Harrison FW, Gardiner SL (eds) Microscopic anatomy of invertebrates, vol 7. Annelida. Wiley-Liss, New York, pp 217-322

Jamieson BGM (2006) Non-leech Clitellata. In: Rouse G, Pleijel F (eds) Reproductive biology and phylogeny of Annelida. Science Publishers, Enfield, pp 235-392

Jörgensen M (1908) Untersuchungen über die Eibildung bei Nephelis vulgaris Mogiun Tandon (Herpobdella atomaria Carena). Arch Zellforsch 2:279-347

Jörgensen M (1913) Zellstudien II. Die Ei und Nahrzellen von Piscicola. Arch Zellforsch 10:127-160

Kloc M, Biliński S, Dougherty MT, Brey EM, Etkin LD (2004) Formation, architecture and polarity of female cyst in Xenopus. Dev Biol 266:43-61

Lechenault H (1968) Etude cytochimique et ultrastructurale de l'ovocyte d'Eisenia foetida (Sav.). Z Zellforsch 90:96-112

Marotta R, Ferraguti M, Erséus C (2003) A phylogenetic analysis of Tubificinae and Limnodriloidinae (Annelida, Clitellata, Tubificidae) using sperm and somatic characters. Zool Scr 32:255-278

Marotta R, Ferraguti M, Erséus C, Gustavsson LM (2008) Combineddata phylogenetics and character evolution of Clitellata (Annelida) using $18 \mathrm{~S}$ rDNA and morphology. Zool J Linn Soc Lond 154:1-26

Matova N, Cooley L (2001) Comparative aspects of animal oogenesis. Dev Biol 231:291-320

McHugh D (1997) Molecular evidence that echiurans and pogonophorans are derived annelids. Proc Natl Acad Sci USA 94:8006-8009

McHugh D (2000) Molecular phylogeny of the annelids. Can J Zool 78:1873-1884

McKearin D, Dansereau DA, Lasko P (2005) Oogenesis. In: Gilbert LI, Iatrou K, Gill SS (eds) Comprehensive molecular insect science, vol 1. Reproduction and development. Elsevier, Amsterdam, pp 39-85 
Nielsen C (1995) Animal evolution. Oxford University Press, Oxford

Ong S, Tan C (2010) Germline cyst formation and incomplete cytokinesis during Drosophila melanogaster oogenesis. Dev Biol 337:84-98

Paschma M (1962) The structure of the ovary and oogenesis in Enchytraeus albidus Hentle. Zool Pol 12:145-188

Pepling ME, Spradling AC (1998) Female mouse germ cells form synchronously dividing cysts. Development 125:3323-3328

Pepling ME, de Cuveas M, Spradling AC (1999) Germline cysts: a conserved phase of germ cells development? Trends Cell Biol 9:257-262

Purschke G (2002) Male genital organs, spermatogenesis and spermatozoa in the enigmatic terrestrial polychaete Parergodrilus heideri (Annelida, Parergodrilidae). Zoomorphology 121:125-138

Purschke G, Westheide W, Rohde D, Brinkhurst RO (1993) Morphological reinvestigation and phylogenetic relationship of Acanthobdella peledina (Annelida, Clitellata). Zoomorphology 113:91-101

Rousset V, Pleijel F, Rouse GW, Erséus C, Siddall ME (2007) A molecular phylogeny of annelids. Cladistics 23:41-63

Rousset V, Plaisance L, Erséus C, Siddall ME, Rouse GW (2008) Evolution of habitat preference in Clitellata (Annelida). Biol $\mathbf{J}$ Linn Soc 95:447-464

Shimizu T (1996) Ooplasmic redistribution in Tubifex eggs with selectively impaired cortical actin cytoskeleton. Dev Biol 180:54-62

Siddall ME, Apakupakul K, Burreson EM, Coates KA, Erséus C, Gelder SR, Källersjö M, Trapido-Rosenthal H (2001) Validating Livanow: molecular data agree that leeches, branchiobdellidans, and Acanthobdella peledina form a monophyletic group of Oligochaetes. Mol Phylogenet Evol 21:346-351
Siekierska E (2003) The structure of the ovary and oogenesis in the earthworm, Dendrobaena veneta (Annelida, Clitellata). Tissue Cell 35:252-259

Spałek-Wołczyńska A, Klag J, Bielecki A, Świątek P (2008) Oogenesis in four species of Piscicola (Hirudinea, Rhynchobdellida). J Morphol 269:18-28

Świątek P (2005a) Structure of the germinal vesicle during oogenesis in leech Glossiphonia heteroclita (Annelida, Hirudinea, Rhynchobdellida). J Morphol 263:330-339

Świątek P (2005b) Oogenesis in the leech Glossiphonia heteroclita (Annelida, Hirudinea, Glossiphonidae). I Ovary structure and previtellogenic growth of oocytes. J Morphol 266:309-318

Światek P (2006) Oogenesis in the leech Glossiphonia heteroclita (Annelida, Hirudinea, Glossiphonidae). II Vitellogenesis, follicular cell structure and egg shell formation. Tissue Cell 38:263-270

Świątek P (2008) Ovary cord structure and oogenesis in Hirudo medicinalis and Haemopis sanguisuga (Clitellata, Annelida): remarks on different ovaries organization in Hirudinea. Zoomorphology 127:213-226

Świątek P, Kubrakiewicz J, Klag J (2009) Formation of germ-line cysts with a central cytoplasmic core is accompanied by specific orientation of mitotic spindles and partitioning of existing intercellular bridges. Cell Tissue 337:137-148

Świątek P, Krok F, Bielecki A (2010) Germ-line cysts are formed during oogenesis in Erpobdella octoculata (Annelida, Clitellata, Erpobdellidae). Invertebr Reprod Dev 54:53-63

Urbańska-Jasik D (1988) The ultrastructure of female reproductive cells in the ovary of Herpobdella octooculata (L.). Zool Pol 35:127-140

Westheide W (1997) The direction of evolution within the Polychaeta. J Nat Hist 31:1-15 